\title{
Break-Even Analysis in Healthcare Setup
}

\author{
${ }^{1}$ Pranav Kumar Choudhary, ${ }^{2}$ Saroj Kumar Patnaik, ${ }^{3}$ Madhav Madhusudan Singh, ${ }^{4}$ Ginny Kaushal
}

Keywords: Break-even analysis, Cost-volume profit analysis, Multiproduct/service organization, Total fixed expenses, Weighted average selling price, Weighted average variable expenses, Total revenues, Total costs.

How to cite this article: Choudhary PK, Patnaik SK, Singh MM, Kaushal G. Break-Even Analysis in Healthcare Setup. Int J Res Foundation Hosp Healthc Adm 2013;1(1):29-32.

\section{Source of support: Nil}

\section{Conflict of interest: None}

\section{INTRODUCTION}

Break-even analysis is the use of a simple mathematical formula to determine the sales level at which the business is neither incurring a loss nor making a profit. In other words, when the firm's total expenses equal it's net sales revenue that is the break-even point for the operation. ${ }^{1}$

The break-even point (BEP) is, in general, the point at which the gains equal the losses. A BEP defines when an investment will generate a positive return or also the point where total costs equal total revenues. There is no profit made or loss incurred at the break-even point. This is important for anyone who manages a business, since the BEP is the lower limit of profit when prices are set and margins are determined.

Break-even analysis, sometimes called cost-volumeprofit analysis, is an important analytical technique used to study relations among costs, revenues and profits. Both graphic and algebraic methods are employed. For simple problems, simple graphic methods work best. In more complex situations, analytic methods, possibly involving spreadsheet software programs are preferable.

Defining the break-even point in mathematical terms is simply the point where:

Total expenses $=$ Net sales revenue

\footnotetext{
${ }^{1}$ Resident Medical Officer, ${ }^{2,3}$ Medical Officer (Hospital Services) ${ }^{4}$ Faculty

${ }^{1}$ KEM Hospital, Lower Parel, Mumbai, Maharashtra, India

${ }^{2,3}$ Armed Forces Medical Services, India

${ }^{4}$ INLEAD, Gurgaon, Haryana, India
}

Corresponding Author: Pranav Kumar Choudhary, Room No. 82, 4th Floor, Shram Safalya Building, Parel (E), Mumbai 400012 Maharashtra, India, e-mail: skua007@rediffmail.com
The amount of sales revenue should be readily available on income as 'Net Sales'. Net sales revenue is all sales revenue (often called gross revenue) less any sales returns and allowances or sales discounts.

The break-even point represents the level of revenue that equals the total of the variable and fixed costs for a given volume of output service at a particular capacity use rate. Other things being equal, the lower the break-even point, the higher the surplus and the less the operating risk. The BEP also provides nonprofit managers with insights into surplus/deficit planning.

The following case studies will elucidate the concept of break-even analysis.

\section{CASE REPORTS}

\section{Case 1}

A hospital is offering laparoscopic cholecystectomy at a package deal with a selling price ₹ 30,000 /- per operation and the variable cost per operation comes out to be ₹ $20,000 /-$. The annual fixed cost is ₹ 60,00,000/-. How many laparoscopic operation the hospital must do to come at BEP.

\section{Solution}

Total fixed cost $=₹ 60,00,000$

Unit selling price $=₹ 30,000$

Unit variable cost $=₹ 20,000$

Unit contribution $=$ unit selling price-unit variable $=30,000$ $-20000=10,000$

Therefore, BEP (units) $=60,00,000 / 10,000=600$ numbers of laparoscopic operation.

Thus, a minimum number of 600 operations must be done so that the hospital achieves breaks-even point.

\section{Case 2}

An X-ray center has priced its X-ray test and report for ₹ 200/- each. The variable cost is ₹ $100 /$ - per test. The annual fixed cost is ₹ 2,00,000/-. Find out the number of X-ray tests to be performed per year for BEP to be achieved.

\section{Solution}

Total fixed cost $=₹ 2,00,000$

Unit selling price $=₹ 200$

Unit variable cost $=₹ 100$

Therefore, BEP $($ units $)=200,000 /(200-100)=2000$. 
Thus, a minimum of $2000 \mathrm{X}$-ray tests must be carried out so that the X-ray center breaks even.

Thus, break even analysis in an institution leads to a point where there is no profit or loss, i.e. where revenue and expenditure match. In public sector hospitals this sort of analysis is usually not done as there is no such pressing requirement. In private hospitals this has to be made. Otherwise the hospitals will not know whether that the hospital is making a profit or going in loss.

\section{DISCUSSION}

Break-even analysis attempts to study the revenue and costs in relation to sales volume of a business unit and to determine that point where sales revenue just equals to total costs. The level of activity is generally termed as break-even point (BEP). At this point of activity (production/sales), a producer neither earns any profit nor incurs any loss. That is why it is also called as 'No Profit, No Loss Point', or 'Zero Profit and Zero Loss Point'. If sales exceed Break-even point, profit arises and if sales fall below break-even point, loss emerges. Thus break-even point is also known as point at which loss ceases and above which profit begins.

Break-even analysis assists the provider in predicting the volume of services that must be provided (and for which payment must be received) in order for the cost of providing the services to be equally matched by the payment received, yielding neither a profit nor a loss.

For the purpose of this analysis, the various costs are divided in two parts, i.e. fixed costs and the variable costs. The fixed costs are the costs that cannot be avoided and are essential for the business. These remain fixed irrespective of the changes in the volume, i.e. the numbers of units of goods produced such as rent, insurance, etc. Variable costs are costs that vary directly with the number of products produced. The difference between selling price per unit and variable cost per unit is called contribution per unit or simply unit contribution. The sum total of all unit contribution is called 'Total Contribution'. In BEP, the total contribution is equal to the fixed cost. Thus at break even point, the fixed cost has been overcome by the contribution and any further activity would have additional contribution to generate profit. In a break even analysis we would determine this point BEP.

Break-even analysis determines the service output at which total revenue will equal the total costs of an organization. $^{2}$

Assuming that the output of services is ' $\mathrm{x}$ ' and the price is ' $p$ ', then total revenue is ' $x p$ '. If fixed costs are ' $a$ ', and ' $b$ ' is the variable cost per unit of service then the total costs are ' $a+b x$ '. The algebraic expression of the break-even condition (total costs equal total revenues) will then be:

$$
\mathrm{xp}=\mathrm{a}+\mathrm{bx}
$$

And, the BEP, i.e. the service output at which costs and revenues are equal, can be determined as:

$$
\mathrm{x}=\mathrm{a} /(\mathrm{p}-\mathrm{b})
$$

Equations (1) and (2) hold true within the service output range for which the fixed costs and unit variable costs remain constant.

As long as ' $p$ ' is somewhat bigger than ' $b$ ' (i.e. the price is higher than the variable unit cost), so that at least some element of fixed costs is being covered, then, with each additional unit of service, the hospital makes a step toward its BEP. It will take the sale of a certain number of units of service to recover fixed costs. Beyond that number, each additional unit of service sold will generate a surplus of revenue over cost. Figure 1 provides a graphical illustration of the breakeven condition and point. ${ }^{2,3}$

Many organizations sell a combination of different products or services. The sales mix is the roportion of different products or services that an organization sells.

Most of the hospitals or clinics have more than one service. It may be possible to identify the specific fixed costs associated with each service, and so calculate each service's BEP. However, there would still be a core of fixed costs, such as the rent for the buildings and the salary costs of senior management, which cannot be allocated to individual service. If we are to discover the BEP for the whole firm we need to be able to:

- Combine all the fixed costs into a single pool.

- Obtain a surrogate for the contribution per unit that is used to calculate the BEP for a single service.

It will not be possible to use an average contribution per unit in those firms that produce service which are very different from each other. The calculation of a weighted average contribution per unit is time consuming so a surrogate is useful. Hospital is a service industries do not have tangible products, but the units of output can be identified which are connected to selling prices. A multi product/service organisation like hospital can compute its break-even point using the following formula:

$$
\begin{aligned}
& \text { Break-even point }= \\
& \frac{\text { Total fixed expenses }}{\text { Weighted average selling price - }} \\
& \text { weighted average variable expenses }
\end{aligned}
$$

For computing BEP of a company with two or more products/service, we must know the sales percentage of individual products/service in the total sales mix. This information is used in computing weighted average selling price and weighted average variable expenses.

In the above formula, the weighted average selling price is worked out as follows: 
Sale price of product/service $\mathrm{A} \times$ sales percentage of product/service $\mathrm{A}+$ sale price of product/service $\mathrm{B} \times$ sale percentage of product/service B + Sale price of product/ service $\mathrm{C} \times$ sales percentage of product/service $\mathrm{C}+\ldots$ and the weighted average variable expenses are worked out as follows:

Variable expenses of product/service $A \times$ sales percentage of product/service $A+$ Variable expenses of product/service $\mathrm{B} \times$ variable expenses of product/service $\mathrm{B}$ + variable expenses of product/service $C \times$ sales percentage of product/service $\mathrm{C}+\ldots$

When weighted average variable expenses per unit are subtracted from the weighted average selling price per unit, we get weighted average contribution margin per unit. Therefore, the above formula can also be written as follows:

Total fixed expenses

Weighted average contribution margin per unit

The hospital is a multiproduct/ service organization. Sustainable performance above the BEP depends on the sum of performances across many services and cost centers. Decline in the output of services in one clinical department will cause a shortfall of revenue that throws the facility left of the BEP and into deficit (Figure 1). The hospital will have to close the gap either by increasing reimbursable or budgeted activities in other revenue-earning cost centers, or by reducing costs in the intermediate cost centers (taking care not to jeopardize the quality of patient care). The break-even analysis shows the percent by which price and outputs should be increased in each final cost center (or costs should be reduced in each intermediate cost center) in order to restore the hospital to its BEP, for each percent revenue shortfall in a given revenue-earning cost center.

A basic break-even analysis chart composed of a firm's total cost and total revenue curves is depicted in Figure 1. Volume of output is measured on the horizontal axis; revenue and cost are shown on the vertical axis. Fixed costs are constant regardless of the output produced and are indicated by a horizontal line. Variable costs at each output level are measured by the distance between the total cost curve and the constant fixed costs. The total revenue curve indicates the price/demand relation for the firm's product; profits or losses at each output are shown by the distance between total revenue and total cost curves.

\section{ADVANTAGES OF THE BREAK EVEN CHART ${ }^{4,5}$}

1. It serves as a useful tool of planning and control.

2. It is useful tool to study the feasibility of acquiring the equipment.

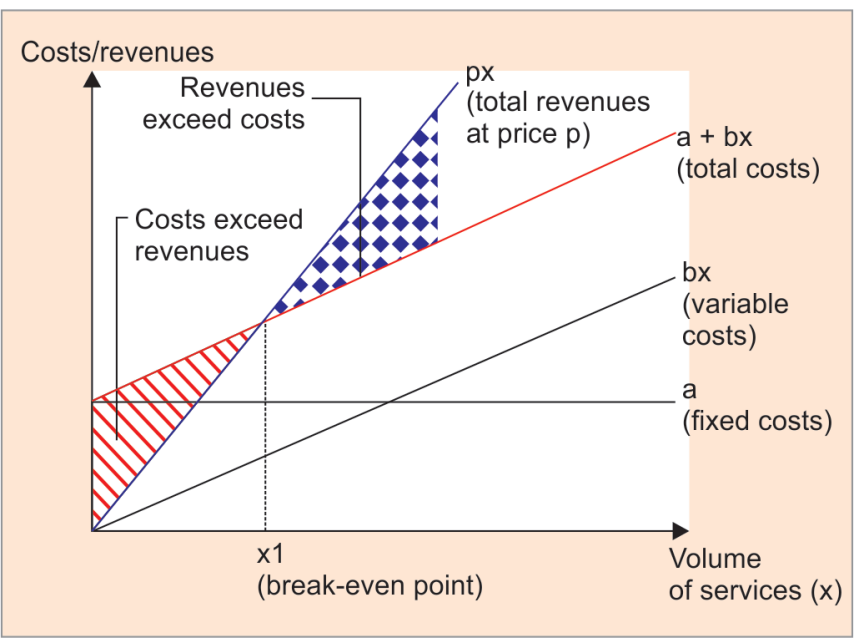

Fig. 1: Break-even analysis

3. It helps to explain relations among volume, prices and costs. It is also useful for pricing, cost control and other financial decisions.

4. It's practical implications are profit estimation at the different levels of activity, ascertaining turnover for desired profit.

5. The main advantage of break-even analysis is that it explains the relationship between cost, production volume and returns. It can be extended to show how changes in fixed cost-variable cost relationships, in commodity prices, or in revenues, will affect profit levels and BEP.

6. Break-even analysis is most useful when used with partial budgeting or capital budgeting techniques.

7. The major benefit to using break-even analysis is that it indicates the lowest amount of business activity necessary to prevent losses.

\section{LIMITATIONS OF BREAK-EVEN ANALYSIS}

1. It is best suited to the analysis of one product at a time.

2. It may be difficult to classify a cost as all variable or all fixed.

3. There may be a tendency to continue to use a breakeven analysis after the cost and income functions have changed.

4. It ignores the price and technology changes and efficiency. ${ }^{6}$

\section{CONCLUSION}

Break-even analysis is a simple tool for financial analysis so as to make a right decision in business proposals when more than one alternative is available. The break-even analysis is most commonly used to do the cost volume profit analysis. It indicates the level of sales at which the total revenues are 
equal to the total costs. For every unit of goods produced the sale/activity generates revenue and the difference of the price minus variable cost is called unit contribution. ${ }^{7,8}$

It is an efficient and effective method of financial reporting and planning and easily understood by the senior executives when compared to accounting data. ${ }^{9}$

\section{REFERENCES}

1. Rezapour A, Arabloo J, Soleimani MJ, Azar FEF, Safari H. Microeconomic Analysis of Healthcare Services in Bou Ali Sina University Hospital. International Journal of Hospital Research 2012, 1(1):41-50.

2. Cavanaugh K. Management Accounting System for Hospitals (MASH) Manual. Partners for Health Reform Plus October 2004; p. 41-43.

3. Wordsworth S, Ludbrook A, Caskey F, Macleod A. Collecting unit cost data in multicentre studies. Creating comparable methods. Eur J Health Econ 2005;6(1):38-44.
4. Browils R. Administrative complement and managerial efficiency in South Carolina hospitals. Hosp Health Serv Adm 1992;37(3):373-386.

5. Gupta SP. Management Accounting. Sahitya Bhavan, Agra, 2003 edn. p. 400-401.

6. Lin BY, Chao TH, Yao Y, Tu SM, Wu CC, Chern JY, Chao SH, Shaw KY. How can activity-based costing methodology be performed as a powerful tool to calculate costs and secure appropriate patient care? J Med Syst 2007;31(2):85-90.

7. Courtney M, Briggs D. Health Care Financial Management. Sydney: Elsevier Mosby 2004:156-168.

8. Saywell RM, Cordell WH, Nyhuis AW, Giles BK, Culler SD, Woods JR, Chu DK, McKinzie JP, Rodman GH: The use of a break-even analysis: financial analysis of a fast-track program. Academic Emergency Medicine 1995;2:739-745.

9. Report from the Second American Thoracic Society Workshop on Outcomes Research: understanding Costs and CostEffectiveness in Critical Care. Am J Respir Crit Care Med 2002;165:540-550. 